\title{
BENTUK PERLINDUNGAN HUKUM TERHADAP PEMEGANG HAK TERKAIT (NEIGHBOURING RIGHTS)
}

\author{
Zulvia Makka \\ Fakultas Hukum Universitas Borneo Tarakan \\ Jl. Amal Lama No.1 Tarakan \\ zulviamakka@gmail.com
}

\begin{abstract}
ABSTRAK
Hak terkait adalah hak yang berkaitan dengan hak cipta yang merupakan hak ekslusif bagi pelaku pertunjukan, producer fonogram, atau lembaga penyiaran. Berdasarkan pengertian hak terkait tersebut maka dapat dipahami bahwa yang merupakan pemilik hak terkait adalah pelaku pertunjukan, produser fonogram (lebih dikenal sebagai produser rekaman), dan lembaga penyiaran. Perlu adanya perlindungan untuk pelaku karena pelaku pertunjukan memiliki hak moral dan hak ekonomi yang terdapat pada pasal 23 UUHC. Yang memuat pada pelaku pertunjukan yang tidak dapat dihilang atau tidak dapat dihapus dengan alasan apapun. Namun pada prakteknya seringkali hak terkait ini dikesampingkan, karena lingkup perlindungan tidak hanya mencakup hak ekonomi dan hak moral. Permasalahan diatas menimbulkan isi hukum bentuk perlindungan terhadap hak terkait menurut undang-undang Hak Cipta dan perolehan Hak Terkait dalam Hak Cipta Isu hukum ini diteliti dengan menggunakan metode dengan tipe penelitian Normatif.

Bentuk pelindungan Hukum terhadap Hak Terkait menurut Undang-Undang Hak Cipta terdiri dari 2 (dua) yaitu, perlindungn hukum preventif dan perlindungan hukum represif. Perolehan hak terkait dalam UUHC yaitu hak moral dan hak ekonomis. Hak moral pelaku pertunjukan merupakan hak yang melekat pada pelaku pertunjukan yang tidak dapat dihilangkan atau tidak dapat dihapus dengan alasan apapun walaupun hak terkait telah dialihkan. Hak Ekonomi Pelaku Pertunjukan adalah suatu hak yang diberikan oleh Undang-undang secara eksklusif kepada Pencipta untuk untuk memanfaatkan keuntungan suatu ciptaan yang biasanya berupa publikasi suatu salinan ciptaan atau fonogram supaya dapat tersedia untuk publik dalam jumlah tertentu.
\end{abstract}

\section{Kata Kunci : Perlindungan, Hak Terkait, Hak Moral, Hak Ekonomi}

\begin{abstract}
Related rights are rights relating to copyright which are exclusive rights for performers, producer phonograms, or broadcasters. Based on the understanding of related rights, it can be understood that those who are related rights holders are performers, phonogram producers (better known as record producers), and broadcasting institutions. There needs to be protection for the perpetrators because the performers have the moral rights and economic rights contained in article 23 of UUHC. Which includes the performers who cannot be lost or cannot be removed for any reason. But in practice often these related rights are ruled out, because the scope of protection does not only cover economic rights and moral rights. The above issues give rise to the contents of the law in the form of protection of related rights according to
\end{abstract}


the Copyright law and the acquisition of Related Rights in Copyright This legal issue is examined using methods with normative research types.

The form of legal protection against Related Rights according to the Copyright Act consists of 2 (two), namely, preventive legal protection and repressive legal protection. The acquisition of related rights in the UUHC is moral rights and economic rights. The moral rights of performers are the rights inherent in the performers who cannot be removed or cannot be removed for any reason even though the related rights have been transferred. The Economic Rights of Performers is a right granted by the Law exclusively to the Creator to utilize the benefits of a work which is usually in the form of the publication of a copy of a work or phonogram so that it can be available to the public in a certain amount.

Keywords: Protection, Related Rights, Moral Rights, Economic Rights

\section{A. PENDAhuluan}

Undang-Undang Nomor 28 Tahun 2014 tentang Hak Cipta Lembar Negara Nomor 5599 yang selanjutnya disebut UUHC. Secara keseluruhan mengatur tentang Hak Cipta. Hak Cipta (copyright) merupakan subsistem dari Hak Kekayaan Intelektual (HKI) yang secara internasional disebut dengan Intellectual Property Right (IPR). HKI dibagi atas dua kelompok besar, yakni Hak Milik Perindustrian (Industrial Property Right) dan Hak Cipta (Copyright). Yang termasuk kelompok Hak Milik Perindustrian, antara lain Paten (Patents), Merek Dagang (Trademarks), Desain Industri (Industrial Design), Rahasia Dagang (Undisclosed Information), Indikasi Geografis (Geographical Indication), model dan Rancang Bangun (Utility Models), dan Persaingan Curang (Unfair Competition), sedangkan yang termasuk kelompok hak cipta dibedakan antara hak cipta ( atas seni, sastra, dan ilmu pengetahuan) dan hak-hak yang terkait dengan hak cipta (Neighbouring Right). ${ }^{1}$ Jadi HAKI tidak hanya sebatas pada Hak Cipta akan tetapi terbagi atas Hak Merek, Hak Paten, Rahasia Dagang, Desain Industri, Desain Tata Letak dan Sirkuit Terpadu serta Varietas Tanaman.

Di Indonesia, keberadaan pengaturan mengenai hak cipta dimulai dengan diterbitkanya Unndang-undang Hak Cipta Nomor 6 Tahun 1982 yang diberlakunya oleh pemerintah untuk menggantikan Auteurswet 1912 peninggalan Belanda. Setelah Undang-undang Hak Cipta Tahun 1928, berturutturut dilakukan perubahan terhadap undang-undang hak cipta di Indonesia, diantaranya Undang-Undang Hak Cipta No.7 Tahun 1987 yang kemudian diubah

1 Otto Hasibuan, Hak Cipta Di Indonesia, Bandunng, Alumni, 2008, h.21 
menjadi Undang-undang No. 12 Tahun 1997 tentang Perubahan atas UndangUndang No.7 Tahun 1987.2

Dikeluarkanya Undang-undang Hak Cipta No. 12 Tahun 1997 ini sebenarnya merupakan konsekuensi atas keikutsertaan Indonesia dalam Organisasi Perdagangan Duni (WTO), di mana Indonesia telah meratifikasi perjanjian tersebut dalam Undang-undang No.7 Tahun 1994 tentang pengesahan Agreement Establishing The World Trade Organization. Dengan demikian, segala perangkat perundangan-undangan yang menyangkut hak kekayaan intelektual harus disesuaikan atau merujuk pada ketentuan yang ada dalam TRIPS (Trade Related Intellectual Property Right) yang dihasilkan oleh WTO. Pada tahun 2002, pemerintah kembali melakukan penggantian undangundang hak cipta dengan menetapkan Undang-Undang Hak Cipta No.19 Tahun 2002 Tentang Hak Cipta (selanjutnya disebut UUHC) sebagai undang-undang yang baru. ${ }^{3}$

UUHC Indonesia Nomor 28 tahun 2014 tentang Hak Cipta, terdiri dari 126 pasal (seratus dua puluh enam pasal) menggantikan Undang-Undang Republik Indonesia Nomor 19 tahun 2002. Lahirnya UUHC yang baru ini dilandasi perkembangan ilmu pengetahuan, teknologi, seni, dan sastra sudah demikian pesatnya, sehingga memerlukan peningkatan perlindungan dan jaminan kepastian hukum bagi pencipta, pemegang Hak Cipta dan Pemilik Hak Cipta.

Hak Cipta adalah hak eksklusif pencipta yang timbul secara otomatis berdasarkan prinsip deklaratif setelah suatu ciptaan diwujudkan dalam bentuk nyata tanpa mengurangi pembatasan sesuai dengan ketentuan peraturan perundang-undangan". ${ }^{4}$ Ketentuan UUHC menekankan pada Hak Eksklusif yang keberadaannya melekat erat kepada pemiliknya atau pemegangnya yang merupakan kekuasaan pribadi atas ciptaan yang bersangkutan dan bernilai dengan uang. Untuk itu tidak ada pihak yang dapat memanfaatkan Hak Cipta kecuali atas izin pencipta. ${ }^{5}$ Hak eksklusif yang dimiliki pencipta tidak bisa

2 Yusran Isnaini, Hak Cipta dan tantanganya di era cyber space, Ghalia Indonesia, Bogor, 2009, h.9

${ }^{3}$ Ibid,h. 9

${ }^{4}$ UU No. 28 tahun 2004 tentang Hak Cipta, LN No. 5599, Pasal 1 angka (1).

5 Gatot Supramono, Hak Cipta Dan Aspek-Aspek Hukumnya, Rineka Cipta, Jakarta, 2010, h. 44 
dipisahkan karena hak tersebut dapat dituntut apabila hak tersebut dilanggar. Hak Eksklusif dalam Hak Cipta terbagi atas Hak Ekonomi (economic rights) dan Hak Moral (moral rights).

UUHC memberikan kepada seseorang pengarang atau pencipta atas sebuah ciptaan, hak ekslusif atas karya kayanya untuk jangka waktu tertentu. Hak-hak ini memungkinkan para pencipta untuk mengawasi pemanfaatan hak ekonomi atas karya-karya mereka dengan sejumlah cara, dan untuk itu mereka tentu berhak atas sejumlah sejumlah pembayaran. UUHC juga memberikan hak moral yang melindungi, antara lain citra dan integritas pencipta. Hak moral adalah hak pencipta hak pencipta yang untuk mengklaim sebagai pencipta atas suatu hasil ciptaan dan hak pencipta untuk mengajukan keberatan-keberatan terhadap setiap perbuatan yang bermaksud untuk mengubah, mengurangi atau menambah keaslian ciptaan, yang akan dapat meragukan kehormatan dan reputasi pencipta pertama. Penjelasan Pasal 4 UUHC menjelaskan bahwa Hak yang dimaksud dengan hak ekslusif adalah hak yang hanya diperuntukkan bagi pencipta, sehingga tidak ada pihak lain yang dapat memanfaatkan hak tersebut tanpa izin pencipta. Pemegang hak cipta yang bukan pencipta hanya memiliki sebagain dari hak ekslusif berupa hak ekonomi.

Pada Pasal 9 UUHC menjelaskan Hak eksklusif si pemegang hak cipta termasuk kegiatan-kegiatan menerjemakan, mengadaptasi, mengaransemen, mengalihwujudkan, menjual, menyewa, meminjamkan, mengekspos, serta mengkomunikasikan suatu ciptaan kepada pubik melalui sarana apapun. Hakhak ekslusif yang tercakup dalam hak cipta dapat diahlikan misalkan dengan pewarisan atau perjanjian tertulis seperti yang diatur pada UUHC Pasal 16. Pemilik hak cipta dapat pula mengizinkan pihak lain melakukan hak ekslusifnya tersebut dengan lisensi, dengan persyratan tertetntu. Selain hak-hak ekslusif ini (yang merupakan hak ekonomi), Konvensi Bern juga mengatur sekumpulan hak yang dinamakan hak-hak moral (driot moral). Hak moral merupakam hak yang meliputi kepentingan pribadi (individu). Hak moral melekat pada pribadi pencipta, hak moral yang dalam keadaan bagaimana pun dan dengan jalan apapun tidak dapat ditinggalkan daripadanya, seperti mengumumkan karyanya, menetapkan judulnya, mencantumkan nama sebenarnya atau nama samarannya dan mempertahankan keutuhan atau integritas ceritanya. Dan Hak ekonomi adalah hak untuk memperoleh keuntungan ekonnomi atas kekayaaan intelektual.Dikatakan hak ekonomi karena hak atas kekayaan intelektual adalah 
benda yang dapat dinilai dengan uang. Hak ekonomi tersebut berupa keuntungan sejumlah uang yang diperoleh karena penggunaan sendiri hak atas kekayaan intelekual, atau karena penggunaan oleh pihak lain berdasarkan lisensi. 6

Pada penjelasana umum UUHC menyatakan bahwa Hak Cipta merupakan salah satu bagian dari kekayaan intelektual yang memiliki ruang lingkup objek dilindungi paling luas, karna mencakup ilmu pengetahuan, seni dan sastra (art and literaty) yang didalamya mencakup pula program komputer. Dengan Undang-undang hak cipta yang memenuhi unsur perlindungan dan pengembangan ekonomi kreatif ini maka diharapkan kontribusi sektor hak cipta dan hak terkait bagi perekonomian Negara dapat lebih optimal.

Pembahasaan tentang hak cipta tentu tidak biasa lepas dari satu bagian hak yang akhir-akhir ini semakin kokoh sebagai hak yang berdiri sendiri, yaitu hak yang berkaitan dengan hak cipta atau yang lazim disebut hak terkait (Neighbouring Right). Di dunia internasional sudah ada konvensi tersendiri tentang hak terkait, yaitu Konvensi Roma, sementara di Indonesia pengaturan hak terkait masih menyatu dalam UUHC. Maksud dan tujuan utama diadakanya Konvensi Roma adalah menetapkan pengaturan secara internasional perlindungan hukum tiga kelompok pemegang hak-hak yang berkaitan dengan hak cipta yang sampai sekarang ini hanya terdiri dari tiga kelompok (kemungkinan kelak berkembang lebih) yang dinamakan hak-hak yang berkaitan (Related Rights/ Neighbouring Rights). Tiga kelompok pemegang hak cipta dimaksud adalah : 7

1. Artis-artis pelaku (Performing artists), yang dapat terdiri dari penyanyi,aktor,musisi,penari, dan lain-lain pelaku yang mempertunjukan karya-karya sastra dan seni;

2. Produser-produser rekaman (Producers of Phonogram).

3. Lembaga-lembaga penyiaran (Broadcasting Organization).

Jadi, kalau Pencipta adalah orang yang atas inspirasinya melahirkan karya cipta atau ciptaan, seperti buku,lagu,drama,tari dan sebagainya, pemegang hak terkait adalah orang atau lembaga yang melahirkan karya-karya turunan (derivatine works) daripada karya ciptaan, seperti karya rekaman suara, karya

6Simorangkir, Hak Cipta Lanjutan, Jakarta:Djambatan, 1979, h.39

${ }^{7}$ Otto Hasibuan, Op.Cit.,h.27 
rekaman gambar pertunjukan, dan karya siaran. ${ }^{8}$ Sedangkan hak terkait menurut Pasal 1 angka 5 UUHC merupakan hak eksklusif bagi pelaku pertunjukan, produser fonogram, atau lembaga penyiaran.

Berdasarkan pengertian hak terkait tersebut maka dapat dipahami bahwa yang merupakan pemilik hak terkait adalah pelaku pertunjukan, produser fonogram (lebih dikenal sebagai produser rekaman), dan lembaga penyiaran. Ketiga subjek tersebut ada kalanya bukan pencipta, namun mereka memiliki andil besar dalam mendistribusikan sarana hiburan yang dapat dinikmati dan digunakan oleh masyarakat. Hak terkait lahir dari adanya hak cipta induk, misalnya liputan pertandingan sepakbola atau pertandingan tinju atau live show artis penyanyi adalah hak cipta sinematografi, tetapi untuk penyiarannya di televisi yakni berupa hak siaran adalah hak terkait.

Perlu adanya perlindungan untuk pelaku karena pelaku pertunjukan memiliki hak moral dan hak ekonomi yang terdapat pada pasal 23 UUHC. Yang memuat pada pelaku pertunjukan yang tidak dapat dihilang atau tidak dapat dihapus dengan alasan apapun. Begitu pula dengan pelaku pertunjukan yang memiliki hak ekonomi sebagaimana dimaksud pada pasal ayat 1 pasal 23 UUHC meliputi hak melaksanakan sendiri, memberikan izin, melarang pihak lain untuk melakukan penyiaraan atau komunikasi atas pertunjukan pelaku pertunjukan. Namun pada prakteknya seringkali hak terkait ini dikesampingkan, jika membahas UUHC orang-orang hanya mengganggap UUHC adalah tentang hak cipta semata, padahal didalam Pasal 3 UUHC menjelaskan bahwa UUHC tidak hanya membahas mengenai hak cipta melainkan juga membahas tentang Hak Terkait. Pada Pasal 1 angka 5 UUHC mengartikan hak terkait adalah hak yang berkaitan dengan hak cipta yang merupakan hak ekslusif bagi pelaku pertunjukan, producer fonogram, atau lembaga penyiaran. Berdasarkan pengertian tersebut dapat kita ketahui bahwa yang dapat memiliki hak ekslusif tidak hanya pencipta yang memiliki hak cipta, melainkan pihak lain yang memiliki hak terkaitpun dapat memiliki hak ekslusif dari suatu ciptaan. Berdasarkan penjelasan latar belakang diatas, penulis tertarik menyusun penulisan penelitian hukum dengan judul "Bentuk Perlindungan Hukum Terhadap Pemegang Hak Terkait (Neighbouring Rights)".Bedasarkan uraian

${ }^{8}$ Ibid, h.29 
yang telah dikemukakan pada latar belakang masalah diatas, maka penulis mengemukakan rumusan masalah sebagai berikut :

1. Bentuk Perlindungan Terhadap Hak Terkait Menurut Undang-undang Hak Cipta

2. Perolehan Hak Terkait dalam Undang-undang Hak Cipta

\section{B. METODE PENELITIAN}

Penelitian hukum dilakukan untuk memecahkan isu hukum yang dihadapi. ${ }^{9}$ Berdasarkan sifat penelitian yang di buat oleh penulis ialah tipe penelitian Yuridis Normatif, dengan dua pendekatan yaitu pendekatan konseptual (conseptual approach) dan pendekatan perundang-undangan (statute approach). Adapun teknik analisis yang digunakan dengan pengumpulan bahan hukum yang kemudian mencari penyelesaian masalah yang diangkat dan dilakukan Teknik deskriptif dan interpretasi secara kualitatif.

\section{PEMBAHASAAN}

1. Bentuk Perlindungan Terhadap Hak Terkait Menurut Undang-undang Hak Cipta

Perlindungan hukum bertujuan untuk melindungi subyek-subyek hukum dengan perundang-undangan yang berlaku. Bentuk perlindungan hukum dibedakan menjadi 2, yaitu:

1. Perlindungan Hukum Preventif Perlindungan yang diberikan oleh pemerintah dengan tujuan untuk mencegah sebelum terjadinya pelanggaran. Pada perlindungan hukum preventif ini, subyek hukum diberikan kesempatan untuk mengajukan keberatan atau pendapatnya sebelum suatu keputusan pemerintah mendapat bentuk yang definitif Hal ini terdapat dalam peraturan perundangundangan dengan maksud untuk mencegah suatu pelanggaran serta memberikan rambu-rambu atau batasan-batasan dalam melakukan suatu kewajiban. Bentuk perlindungan hukum preventif dalam hak terkait, diatur dalam pasal undang-undang berikut :

Pasal 106

9 Peter Mahmud Marzuki, Penelitian Hukum, Kencana Prenada Media Group, Jakarta, 2005, h. 60. 
Atas permintaan pihak yang merasa dirugikan karena pelaksanaan Hak Cipta atau Hak Terkait, Pengadilan Niaga dapat mengeluarkan penetapan sementara untuk:

a. mencegah masuknya barang yang diduga basil pelanggaran Hak Cipta atau Hak Terkait ke jalur perdagangan;

b. menarik dari peredaran dan menyita serta menyimpan sebagai alat bukti yang berkaitan dengan pelanggaran Hak Cipta atau Hak Terkait tersebut;

c. mengamankan barang bukti dan mencegah penghilangannya oleh pelanggar; dan/atau

d. menghentikan pelanggaran guna mencegah kerugian yang lebih besar.

Pasal 107

(1) Permohonan penetapan sementara diajukan secara tertulis oleh Pencipta, Pemegang Hak Cipta, pemilik Hak Terkait, atau Kuasanya kepada Pengadilan Niaga dengan memenuhi persyaratan:

a. melampirkan bukti kepemilikan Hak Cipta atau Hak Terkait;

b. melampirkan petunjuk awal terjadinya pelanggaran Hak Cipta atau Hak Terkait;

c. melampirkan keterangan yang jelas mengenai barang dan/atau dokumen yang diminta, dicari, dikumpulkan, atau diamankan untuk keperluan pembuktian;

d. melampirkan pernyataan adanya kekhawatiran bahwa pihak yang diduga melakukan pelanggaran Hak Cipta atau Hak Terkait akan menghilangkan barang bukti; dan

e. membayar jaminan yang besaran jumlahnya sebanding dengan nilai barang yang akan dikenai penetapan sementara.

(2) Permohonan penetapan sementara pengadilan sebagaimana dimaksud pada ayat (1) diajukan kepada ketua Pengadilan Niaga di wilayah hukum tempat ditemukannya barang yang diduga merupakan basil pelanggaran Hak Cipta atau Hak Terkait. 
2. Perlindungan Hukum Represif bertujuan untuk menyelesaikan sengketa. Perlindungan hukum represif ini merupakan perlindungan akhir berupa sanksi seperti denda, penjara, dan hukuman tambahan yang diberikan apabila sudah terjadi sengketa atau telah dilakukan suatu pelanggaran. Prinsip perlindungan hukum terhadap tindakan pemerintah bertumpu dan bersumber dari konsep tentang pengakuan dan perlindungan terhadap hak-hak asasi manusia karena menurut sejarah dari barat, lahirnya konsepkonsep tentang pengakuan dan perlindungan terhadap hak-hak asasi manusia diarahkan kepada pembatasan-pembatasan dan peletakan kewajiban masyarakat dan pemerintah. Prinsip kedua yang mendasari perlindungan hukum terhadap tindak pemerintahan adalah prinsip negara hukum. Dikaitkan dengan pengakuan dan perlindungan terhadap hak-hak asasi manusia, pengakuan dan perlindungan terhadap hak-hak asasi manusia mendapat tempat utama dan dapat dikaitkan dengan tujuan dari negara hukum.

Pasal 95

(1) Penyelesaian sengketa Hak Cipta dapat dilakukan melalui alternatif penyelesaian sengketa, arbitrase , atau pengadilan.

(2) Pengadilan yang berwenang sebagaimana dimaksud ayat (1) adalah Pengadilan Niaga.

(3) Pengadilan lainnya selain Pengadilan Niaga sebagaimana dimaksud ayat (2) tidak berwenang menangani penyelesaian sengketa Hak Cipta.

(4) Selain pelanggaran Hak Cipta dan/atau Hak Terkait dalam bentuk Pembajakan, sepanjang para pihak yang bersengketa diketahui keberadaannya dan/atau berada di wilayah Negara Kesatuan Republik Indonesia harus menempuh terlebih dahulu penyelesaian sengketa melalui mediasi sebelum melakukan tuntutan pidana.

Berdasarkan Pasal 95 bentuk perlindungan hukum represif dalam pelanggaran hak cipta dapat ditempuh melalui mediasi, abritasi, dan pengadilan. Arbitrase merupakan cara penyelesaian suatu sengketa perdata di luar peradilan umum yang didasarkan pada perjanjian arbitrase yang dibuat secara tertulis oleh para pihak yang bersengketa. Mediasi adalah proses penyelesaian sengketa antara para pihak yang dilakukan dengan bantuan pihak ketiga (mediator) yang netral dan tidak memihak sebagai fasilitator, di mana keputusan untuk mencapai suatu kesepakatan tetap 
diambil oleh para pihak itu sendiri. Adapun melalui pengadilan, pengadilan yang berwenang menangani penyelesaian sengketa hak cipta adalah pengadilan niaga.

1. Sanksi Perdata

Sesuai dengan ketentuan Pasal 96 UU Hak Cipta menyatakan bahwa:

(1) Pencipta, pemegang Hak Cipta dan/atau pemegang Hak Terkait atau ahli warisnya yang mengalami kerugian hak ekonomi berhak memperoleh Ganti Rugi.

(2) Ganti Rugi sebagaimana dimaksud pada ayat (1) diberikan dan dicantumkan sekaligus dalam amar putusan pengadilan tentang perkara tindak pidana Hak Cipta dan/atau Hak Terkait.

(3) Pembayaran Ganti Rugi kepada Pencipta, Pemegang Hak Cipta dan/atau pemilik Hak Terkait dibayarkan paling lama 6 (enam) bulan setelah putusan pengadilan yang berkekuatan hukum tetap.

Jadi berdasarkan isi pada Pasal 96 apabila terjadi pelanggaran pemegang hak terkait dalam hak ekonomi maka dapat ditempuh dengan cara pembayaran ganti rugi. Ganti rugi diberikan dan dicantumkan sekaligus dalam amar putusan pengadilan tentang perkara tindak pidana Hak Cipta dan/atau Hak Terkait. Pembayaran Ganti Rugi kepada Pencipta, Pemegang Hak Cipta dan/atau pemilik Hak Terkait dibayarkan paling lama 6 (enam) bulan setelah putusan pengadilan yang berkekuatan hukum tetap.

2. Sanksi Pidana

Apabila terjadi pelanggaran pemegang hak terkait dalam hak ekonomi juga dapat dikenakan sanksi pidana sesuai dengan ketentuan Pasal 116 sampai dengan Pasal 118 UU Hak Cipta.

Pasal 116, menyatakan bahwa :

a. Setiap Orang yang dengan tanpa hak melakukan pelanggaran hak ekonomi sebagaimana dimaksud dalam Pasal 23 ayat (2) huruf e untuk Penggunaan Secara Komersial dipidana dengan pidana penjara paling lama 1 (satu) tahun dan/atau pidana denda paling banyak Rp100.000.000 (seratus juta rupiah).

b. Setiap Orang yang dengan tanpa hak melakukan pelanggaran hak ekonomi sebagaimana dimaksud dalam Pasal 23 ayat (2) huruf a, huruf b, dan/atau huruf f, untuk Penggunaan Secara 
Komersial dipidana dengan pidana penjara paling lama 3 (tiga) tahun dan/atau pidana denda paling banyak Rp500.000.000,00 (lima ratus juta rupiah).

c. Setiap Orang yang dengan tanpa hak melakukan pelanggaran hak ekonomi sebagaimana dimaksud dalam Pasal 23 ayat (2) huruf c, dan/atau huruf d untuk Penggunaan Secara Komersial dipidana dengan pidana penjara paling lama 4 (empat) tahun dan/atau pidana denda paling banyak Rp 1.000.000.000,00 (satu miliar rupiah).

d. Setiap Orang yang memenuhi unsur sebagaimana dimaksud pada ayat (3) yang dilakukan dalam bentuk Pembajakan dipidana dengan pidana penjara paling lama 10 (sepuluh) tahun dan/atau pidana denda paling banyak Rp4.000.000.000,00 (empat miliar rupiah).

Pasal 117, menyatakan bahwa :

a. Setiap Orang yang dengan sengaja dan tanpa hak melakukan pelanggaran hak ekonomi sebagaimana dimaksud dalam Pasal 24 ayat (2) huruf c untuk Penggunaan Secara Komersial dipidana dengan pidana penjara paling lama 1 (satu) tahun dan/atau pidana denda paling banyak Rp100.000.000 (seratus juta rupiah).

b. Setiap Orang yang dengan sengaja dan tanpa hak melakukan pelanggaran hak ekonomi sebagaimana dimaksud dalam pasal 24 ayat (2) huruf a, huruf b, dan/atau huruf d untuk Penggunaan Secara Komersial, dipidana dengan pidana penjara paling lama 4 (empat) tahun dan/atau pidana denda paling banyak Rp1.000.000.000,00 (satu miliar rupiah).

c. Setiap Orang yang memenuhi unsur sebagaimana dimaksud pada ayat (2) yang dilakukan dalam bentuk Pembajakan dipidana dengan pidana penjara paling lama 10 (sepuluh) tahun dan/atau pidana denda paling banyak Rp4.000.000.000,00 (empat miliar rupiah).

Pasal 118, menyatakan bahwa: 
(1) Setiap Orang yang dengan sengaja dan tanpa hak melakukan pelanggaran hak ekonomi sebagaimana dimaksud dalam Pasal 25 ayat (2) huruf a, huruf b, huruf c, dan/atau huruf d untuk Penggunaan Secara Komersial, dipidana dengan pidana penjara paling lama 4 (empat) tahun dan/atau pidana denda paling banyak Rp1.000.000.000,00 (satu miliar rupiah).

(2) Setiap Orang yang memenuhi unsur sebagaimana dimaksud dalam Pasal 25 ayat (2) huruf d yang dilakukan dengan maksud Pembajakan dipidana dengan pidana penjara paling lama 10 (sepuluh) tahun dan/atau pidana denda paling banyak Rp4.000.000.000,00 (empat miliar rupiah).

Berdasarkan uraian diatas dapat dijelaskan bahwa untuk melakukan Perlindungan Hukum Represif terhadap pemegang hak terkait sudah diatur dalam Undang-Undang Hak Cipta yang dimana apabila ada yang melanggar hak terkait maka akan mendapatkan sanksi ganti rugi, denda, dan penjara yang sudah dijelaskan pada uraian diatas yang dimana pemegang hak terkait dalam hak cipta yang merasa telah dilanggar haknya dapat mengajukan gugatan ke Pengadilan Niaga sesuai dengan Undang-Undang yang mengatur.

\section{Perolehan Hak Terkait Dalam Undang-Undang Hak Cipta}

Subjek dalam Hak Terkait ditujukan kepada aktor, penyanyi, pemusik, penari, atau mereka yang menampilkan, memperagakan, mempertunjukan, menyanyikan, mendeklamasikan, atau memainkan suatu karya music, drama, tari, sastra, folkor atau karya seni lainya. ${ }^{10}$ Perolehan hak terkait adalah merupakan orang atau badan hukum yang memiliki tanggung jawab untuk melaksanakan suatu pertunjukkan maupun perekaman.11

Hak Terkait memperoleh atau memiliki hak eksklusif yang meliputi Hak moral Pelaku Pertunjukan, Hak ekonomi Pelaku Pertunjukan, hak ekonomi Produser Fonogram dan Hak ekonomi Lembaga Penyiaran. Hal ini sebagaimana tercantum pada Pasal 20 UUHC.

Hak terkait memperoleh hak yang melekat yang tidak dapat dihilangkan atau dihapus pada pelaku pertunjukan. Selain itu namanya juga dicantumkan

${ }^{10}$ Hak cipta dan tantanganya diera cybwer space yusran isnaini hl.23

${ }^{11}$ Eddy Damian, Glosarium Hak cipta Dan Hak Terkait, Alumni Bandung 2012, h.43 
sebagai pelaku pertunjukan. Serta meperolehan perlindungan dalam hal hal yang bersifat merugikan. Sebagaimana hal ini tercantum dalam Pasal 21 dan Pasal 22.

Hak Terkait yang dimiliki penyanyi dan pemusik masing-masing, mengandung dua unsur hak, yaitu hak moral dan hak ekonomis. Aplikasi dari hak moral tersebut, antara lain Pencipta lagu atau ahli warisnya berhak menuntut Pemegang Hak Cipta supaya nama Pencipta tetap dicantumkan dalam Ciptaanya, suatu Ciptaan tidak boleh diubah walaupun Hak Ciptaanya telah diserahkan kepada pihak lain, kecuali dengan persetujuan Pencipta atau dengan persetujuan ahli warisnya dalam hal Pencipta telah meninggal dunia, dan Pencipta tetap berhak berhak mengadakan perubahaan pada Ciptaanya sesuai dengan kepatutan dalam masyarakat.

Adapun hak ekonomi menurut penjelasan UUHC adalah hak untuk mendapatkan manfaat ekonomi atas Ciptaan serta produk hak terkait. Aplikasi dari hak ini adalah bahwa Pencipta hendaknya mendapatkan manfaat ekonomi berkaitan dengan kegiatan pengumuman atau perbanyakan dari Ciptaanya. Demikian pula pelaku atau penyanyi damn pemusik mendapatkan manfaat ekomomi berkaitan dengan kegiatan pebanyakan dan penyiaran dari rekaman suara dan/atau gambar pertunjukan.

Hak ekonomi seorang pencipta meliputi :

1. Hak reproduksi atau penggandaan (reproduction right);

2. Hak adaptasi (adaptation right);

3. Hak distribusi (distribution right);

4. Hak pertunjukan (public performance right);

5. Hak penyiaran (broadcasting right);

6. Hak program kabel (cablecasting right)

7. Droit de suite, dan

8. Hak pinjam masyarakat (public lending right)

Berikut ini penjelasan tentang kedelapan jenis hak ekonomi diatas :

1. Hak reproduksi atau penggandaan (reproduction right)

Dalam istilah ini Undang-undang Hak Cipta, Hak reproduksi memiliki arti yang sama dengan perbanyakan, yaitu penambahan jumlah sesuatu ciptaan baik secara keseluruhan maupun bagian yang sangat substansial dengan menggunakan bahan-bahan yang sama ataupun tidak, termasuk mengahliwujudkan secara permanen atau temporer. Bentuk penggandaan 
atau perbanyakan ini dapat dilakukan secara tradisional maupun melalui peralatan modern. Hal reproduksi ini juga mencakup perubahaan bentuk ciptaan satu kebentuk ciptaan lainya, misalnya rekaman music, pertunjukan drama, juga pembuatan duplikat dalam rekaman suara dan filim.

2. Hak adaptasi (adaptation right)

Hak untuk mengadakan adaptasi dapat berupa penerjemahan dari bahasa satu ke bahasa lain, aransemen music, dramatisasi, dari nondramatic, mengubah menjadi cerita fiksi dari karangan nonfiksi atau sebaliknya.

3. Hak distribusi (distribution right);

Hak distribusi adalah hak yang dimiliki pencipta untuk menyebarkan kepada masyarakat setiap hasil ciptaanya. Penyebaran tersebut dapat berupa penjualan, penyewaan, atau bentuk lain yang dimaksudkan agar ciptaan tersebut dikenal oleh masyarakat.

4. Hak pertunjukan (performance right)

Hak ini dimiliki oleh para pemusik, dramawan, maupun senian lainya yang karyanya dapat diungkapkan dalam pertunjukan. Dalam UUHC, hak penampilan ini menjadi bagian dalam istiilah yang disebut pelaku, yaitu aktor, penyanyi, pemusik, penari, atau mereka yang menampikan, memperagakan,mempertunjukan,menyajikan,menyampaikan,mendeklamasi kan, atau memainkan suatu karya music, drama, tari, sastra, folklore, atau karya seni lainya.

5. Hak penyiaran (broadcasting right)

Hak untuk menyiarakan dapat berupa menstranmisikan suatu ciptaan dengan atau tanpa peralatan kabel atau melalui sistem elektromagnetik. Termasuk dalam pengertian menyiarkan adalah menyewakan, melakukan pertunjukan umum (public performance), mengomunikasikan pertunjukan langung (life performance) dan mengomunikasikan secara interaktif suatu karya rekaman pelaku.

6. Hak program kabel (cablecasting right)

Hak ini hampir sama dengan hak penyiaraan, hanya saja mentransmisikanya melalui kabel. Badan penyiaran televisi mempunyai suatu studio tersendiri, dimana dari tempat ini disiarkan program-program melalui kabel kepada pesawat televisi pelanggan sehingga siaranya dapat dipastikan bersifat komersial. 


\section{Droit de suite}

Droit de suite merupakan hak tambahan pencipta yang bersifat kebendaan. Droit de suite (zaaksgevlog) adalah hak yang mengikuti, artinya hak tersebut terus mengiuti bendanya dimana pun juga (dalam tangan siapa pun) benda itu berada.

8. Hak pinjam masyarakat (public lending right)

Hak ini dimiliki pencipta yang karyanya tersimpan diperpustakaan milik pemerintah, yaitu pencipta berhak atas suatu pembayaran dari pihak tertentu karena karya ciptaanya sering dipinjam oleh masyarakat dari perpustakaan milik pemerintah tersebut.

\section{PENUTUP}

\section{Kesimpulan}

a. Bentuk pelindungan Hukum terhadap Hak Terkait menurut UndangUndang Hak Cipta adalah perlindungn hukum preventif dan perlindungan hukum represif. Perlindungan hukum preventif terdapat dalam undangundang yaitu penetapan sementara pengadilan yang bertujuan untuk mencegah kerugian bagi hak terkait. terhadap pemegang hak terkait sudah diatur dalam Undang-Undang Hak Cipta yang dimana apabila ada yang melanggar hak terkait maka akan mendapatkan sanksi ganti rugi, denda, dan penjara yang dimana pemegang hak terkait dalam hak cipta yang merasa telah dilanggar haknya dapat mengajukan gugatan ke Pengadilan Niaga sesuai dengan Undang-Undang yang mengatur.

b. Hak Terkait yang dimiliki penyanyi dan pemusik masing-masing, mengandung dua unsur hak, yaitu hak moral dan hak ekonomis. Hak moral adalah hak yang melekat dan tidak dapat dihilangkan atau dihapus pada pelaku pertunjukan. Selain itu namanya juga dicantumkan sebagai pelaku pertunjukan. Serta meperolehan perlindungan dalam hal hal yang bersifat merugikan.Hak Ekonomi Pelaku Pertunjukan adalah suatu hak yang diberikan oleh Undang-undang secara eksklusif kepada Pencipta untuk untuk memanfaatkan keekonomian suatu ciptaan suatu ciptaan yang biasanya berupa publikasi suatu salinan ciptaan atau fonogram supaya dapat tersedia untuk publik dalam jumlah tertentu 


\section{Saran}

1. Hak ekonomi pemilik hak terkait telah diatur dalam UU Hak Cipta. Penerapan pelindungan ini harus dilakukan secara konsisten oleh aparat penegak hukum sesuai dengan ketentuan dalam UU Hak Cipta demi kepentingan pemilik hak terkait khususnya dan masyarakat pada umumnya.

2. Perlu adanya pengaturan yang spesifik mengenai mekanisme ganti rugi dan Sebaiknya para pemegang hak terkait segera mendaftrakan ciptaan atau karyanya agar mereka memperoleh hak yang seharusnya mereka dapatkan.

\section{DAFTAR BACAAN}

Damian, Eddy, Glosarium Hak Cipta dan Hak Terkait, Bandung, Alumni, 2012

Djamal,Hukum, Acara Hak Kekayaan Intelektual (HKI), Bandung, Pustaka Reka Cipta, 2009

Hasibuan,Otto, Hak Cipta di Indonesia, Bandung, Alumni, 2008

Hadjon Philipus, Perlindungan Hukum bagi Rakyat Indonesia, Surabaya, Bina Ilmu, 2007

Isnaini, Yusran, Ghalia Indonesia, Hak Cipta dan tantanganya di era cyber space, Bogor, Ghalia Indonesia, 2009

Ishaq, Dasar-dasar Ilmu Hukum, Sinar Grafika, 2016

Jened,Rahmi, Hak Cipta (copyright's Law), Citra Aditya Bakti, 2014

Djumhana dan R. Djubaedilah IV, Hak Milik Intelektual, Bandung, Citra Aditya Bakti, 2003

Lindsay BA, Kekayaan Intelektual Seuatu Pengantar, Bandung, Asian Law Group, 2005

Muhammad Abdulkadir, Hukum Ekonomi Hak Kekayaan Intelektual, Bandung, Citra Aditya Bakti, 2007

Nainggolan Bernard, Pemberdayaan Hukum Hak Cipta dan Lembaga Manajemen Kolektif, Bandung, Alumni, 2011

Simorangkir, Hak Cipta Lanjutan (1979), Jakarta, Djambatan, 1979

Supramono Gatot, Hak Cipta dan Aspek-Aspek Hukumnya, Jakarta, Rineka Cipta, 2007

Undang-undang Nomor 28 tahun 2014 tentang Hak Cipta 